\title{
(6) OPEN ACCESS \\ Occupational health of home care aides: results of the safe home care survey
}

\author{
Margaret M Quinn, ${ }^{1}$ Pia K Markkanen, ${ }^{1}$ Catherine J Galligan, ${ }^{1}$ Susan R Sama, ${ }^{1}$ \\ David Kriebel, ${ }^{1}$ Rebecca J Gore, ${ }^{1}$ Natalie M Brouillette, ${ }^{1}$ Daniel Okyere, ${ }^{1}$ Chuan Sun, ${ }^{1}$ \\ Laura Punnett, ${ }^{1}$ Angela K Laramie, ${ }^{2}$ Letitia Davis ${ }^{2}$
}

\begin{abstract}
${ }^{1}$ Department of Work Environment, University of Massachusetts Lowell, Lowell, Massachusetts, USA ${ }^{2}$ Occupational Health Surveillance Programme, Massachusetts Department of Public Health, Boston, Massachusetts, USA

\section{Correspondence to} Dr Margaret M Quinn, Department of Work Environment, University of Massachusetts Lowell, Lowell, MA 1854, USA; Margaret_Quinn@uml.edu
\end{abstract}

Received 19 April 2015 Revised 17 June 2015 Accepted 3 July 2015 Published Online First 24 July 2015

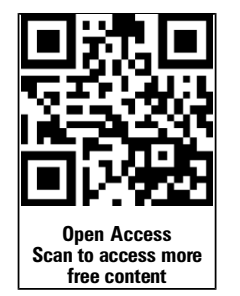

CrossMark

To cite: Quinn MM, Markkanen PK, Galligan CJ, et al. Occup Environ Med 2016;73:237-245.

\section{ABSTRACT}

Objectives In countries with ageing populations, home care (HC) aides are among the fastest growing jobs. There are few quantitative studies of $\mathrm{HC}$ occupational safety and health (OSH) conditions. The objectives of this study were to: (1) assess quantitatively the OSH hazards and benefits for a wide range of $\mathrm{HC}$ working conditions, and (2) compare OSH experiences of HC aides who are employed via different medical and social services systems in Massachusetts, USA.

Methods HC aides were recruited for a survey via agencies that employ aides and schedule their visits with clients, and through a labour union of aides employed directly by clients or their families. The questionnaire included detailed questions about the most recent $\mathrm{HC}$ visits, as well as about individual aides' OSH experiences.

Results The study population included 1249 HC aides (634 agency-employed, 615 client-employed) contributing information on $3484 \mathrm{HC}$ visits. Hazards occurring most frequently related to musculoskeletal strain, exposure to potentially infectious agents and cleaning chemicals for infection prevention and experience of violence. Client-hired and agency-hired aides had similar OSH experiences with a few exceptions, including use of sharps and experience of verbal violence.

Conclusions The OSH experience of $\mathrm{HC}$ aides is similar to that of aides in institutional healthcare settings. Despite OSH challenges, HC aides enjoy caring for others and the benefits of HC work should be enhanced. Quantification of HC hazards and benefits is useful to prioritise resources for the development of preventive interventions and to provide an evidence base for policysetting.

\section{INTRODUCTION}

The global population is ageing. In 2006, nearly 500 million people worldwide were 65 years of age or older; by 2030, that total will increase to 1 billion. ${ }^{1}$ By 2050 in the USA, it is anticipated that Americans aged 65 or older will number nearly 89 million people or be more than double the number of older adults in the USA in 2010. In 2013, Europe had four people of working age for every older person; by 2050, it will have only two workers per older person. The most rapid increases in the 65 and older population are occurring in developing countries, with an increase of $140 \%$ by $2030 .{ }^{1}$

\section{What this paper adds}

- Home care (HC) aides are a largely invisible and yet essential workforce needed to meet the care demands of an ageing population. Although this is one of the fastest growing occupations, there are limited quantitative data describing its' occupational safety and health (OSH) experiences to provide an evidence base for policy-setting.

- This study quantified a wide range of OSH hazards reported by more than $1200 \mathrm{HC}$ aides for nearly $3500 \mathrm{HC}$ visits, including musculoskeletal injury and strain, violence, exposure to infectious agents and cleaning and disinfection chemicals and percutaneous injuries with used sharp medical devices. Despite these experiences, the $\mathrm{HC}$ aides reported high levels of satisfaction with their jobs largely derived from the close relationships they develop with their clients, the ability to work independently and the job flexibility.

- HC aides face a variety of OSH risks that are in many ways similar to those of aides in hospitals and nursing homes. They face additional challenges because their work environment is a private home and they often work alone.

- Policy and educational initiatives to improve the quality of $\mathrm{HC}$ aide work are becoming urgent as the ageing population increases the demand for these critical caregivers. Interventions should enhance the beneficial aspects of $\mathrm{HC}$ work as well as improve OSH.

These profound demographic shifts are driving the need for healthcare for older adults, including home care (HC), at an unprecedented rate. ${ }^{2}$

In the USA and Europe, $\mathrm{HC}$ aide jobs are in high demand and continue to grow rapidly. ${ }^{3-5}$ The US Bureau of Labor Statistics estimates show that there are approximately 2 million home health aides and personal care aides in the USA, ${ }^{6}{ }^{7}$ and predict a $48 \%$ projected growth in the next decade. ${ }^{6}$ In addition to an ageing population, $\mathrm{HC}$ aide jobs are growing due to advances in medical technologies that enable complex procedures to be performed at home, the preference of most people to receive 
care at home, and a decrease in the number of traditional caregivers, mainly women aged $20-60$ years, who are now working outside of the home. ${ }^{28}$

Despite the increasing importance of the HC workforce and growth of the HC industry, few studies have characterised quantitatively HC aides' occupational safety and health (OSH) experiences. $^{9-16}$ Quantitative estimates of OSH risks are needed as a basis for sound policy-setting to promote the health and productivity of this essential workforce. The objectives of this study were to: (1) assess quantitatively the OSH hazards and benefits of a wide range of HC working conditions, and (2) compare $\mathrm{OSH}$ experiences of $\mathrm{HC}$ aides who are employed via different medical and social services systems in eastern Massachusetts, USA.

\section{BACKGROUND}

HC is classified in the North American Industrial Coding System (NAICS) within 'Healthcare and Social Assistance'. There are numerous occupational titles for aides working in HC, including home health aide, certified nursing assistant, hospice aide, personal care aide, personal care attendant and homemaker. For simplicity, we use the term 'HC aide' or 'aide' to refer to the full range of occupational titles. While there are differences in job tasks among occupational titles, there is also considerable overlap. Most aides assist someone in their home with mobility and Activities of Daily Living (ADLs) such as physical exercising, bathing, dressing, toileting, skin care, food preparation and house cleaning. ${ }^{17}$ In the USA, HC recipients are called patients, clients or consumers, depending on how the aide who visits them is hired. For simplicity, we use the term 'client' to refer to all HC recipients. The majority of $\mathrm{HC}$ clients are older adults; aides also care for people of all ages with illness, or physical or cognitive disabilities. HC aides mainly are hired in two different ways: (1) a private business called an agency hires the aide, assigns her to the client and supervises her work, here called 'agency-hired aides', or (2) the client or client's family hires and supervises the aide directly, here called 'client-hired aides'. The average HC visit lasts about 1-2 h for agency-hired aides and can be considerably longer for client-hired aides. The funding to pay for agency-hired and client-hired aides comes through the medical system via health insurance or from the state social services system (Medicare and/ or Medicaid). HC aides also may be hired directly by a client using private funds; evaluation of these aides was outside the scope of this study. In Massachusetts, all aides hired by clients using public funds are represented by a labour union; most agency-hired aides are not in a union.

$\mathrm{HC}$ aides are mainly women and, in the USA, increasingly racial/ethnic minorities and immigrants. ${ }^{18} 19$ The HC aide workforce itself is ageing; the average age years is mid-40 s. ${ }^{20} \mathrm{HC}$ aides are one of the lowest paid occupations in the USA with median annual pay in 2012 approximately $\$ 20000$ (\$20 820 for home health aides ${ }^{6}$ and $\$ 19910$ for personal care attendants ${ }^{7}$ ). The 2015 US poverty line is $\$ 24250$ for a family of four. ${ }^{21}$

\section{METHODS}

\section{Study design}

This study was a cross-sectional questionnaire survey conducted in collaboration with $7 \mathrm{HC}$ aide agencies comprising 16 site locations to recruit agency-hired aides and one $\mathrm{HC}$ aide labour union to recruit client-hired aides. The survey was part of a larger initiative called the Safe Home Care Project, funded by the US National Institute for OSH (NIOSH) at the University of Massachusetts Lowell (UML), Massachusetts, USA, with the mission to promote the OSH of the HC workforce. The Safe Home Care Project employs research-to-practice methods ${ }^{22}$ engaging key stakeholders in the study design and conduct, as well as in interpretation of findings and development of preventive interventions. Accordingly, the survey methods described here were informed by a presurvey qualitative methods study that used focus groups with $\mathrm{HC}$ aides and in-depth interviews with industry and labour representatives to characterise the nature of $\mathrm{HC}$ work and to identify feasible population recruitment methods for this difficult to access population. ${ }^{23}$ Postsurvey focus groups and interviews also were conducted to gain insights about the survey results. All methods and materials were approved by the UML Institutional Review Board (IRB).

\section{Questionnaire development}

Based on discussions with agencies and union representatives, it was determined that the $\mathrm{HC}$ aide population had sufficient language proficiency to complete the questionnaire in English. The questionnaire was designed to be self-administered by the $\mathrm{HC}$ aide. To ensure comprehension and completion in $30 \mathrm{~min}$ or less, it was pilot-tested among HC aides not participating in the study. The pilot-testing methods followed those we developed for an earlier questionnaire survey. ${ }^{24}$ The presurvey focus group and interview findings ${ }^{23}$ informed the development of the survey questions, especially with respect to the range of $\mathrm{OSH}$ topics, professional terminology and work culture.

\section{Units of analysis}

The questionnaire was designed in two parts, each focusing on a different unit of analysis. In part one, the unit of analysis was the individual HC aide, and the questions were asked about demographic information and occupational history. There also were questions on positive incentives for performing $\mathrm{HC}$ work, safety climate and serious health outcomes that may have been experienced by the aide such as injuries and violence occurring in the past 12 months.

In part two of the survey, the unit of analysis was the HC visit, allowing calculation of rates of occurrence of OSH hazards and other aspects of working conditions as a proportion of client visits. The questions were designed to elicit information that could be expressed as a percent of visits in which the hazard/condition was reported. Thus an aide was asked, for example, whether she lifted a client in a particular visit. Typically an aide performs many visits in a week, and the conditions that can impact OSH may be quite different in each home. Gathering hazard data at the visit level allowed us to evaluate this variability, and to summarise working conditions in a more meaningful way than if we had used a question like: "How often do you lift a client?", which would be difficult for the aides to answer given their highly variable experiences. Part two began with questions about hazards/conditions during the most recent $\mathrm{HC}$ visit. This same set of questions was repeated up to the five most recent visits with distinct clients.

\section{Part one, outcome measures}

Sharps injuries: Questions used to evaluate sharps injuries were developed in our previous study. ${ }^{25}$ The questions ascertained whether a HC aide had been stuck or cut by a previously used sharp medical device, such as a needle or lancet, while working in HC. Aides were asked about sharps injuries occurring over two different time intervals: ever in their HC work and number of times in the past 12 months.

Low back pain: The main question to ascertain back pain was: "Have you at any time during the past 12 months had discomfort 
(ache, pain, etc) in your low back?" If yes, the questions that followed ascertained frequency, duration, severity, interference with work and work-relatedness. These were adapted for HC from previously developed questions about musculoskeletal strain experienced by aides in nursing homes. ${ }^{26} 27$

Other injuries: These questions asked whether, in the past 12 months, the aide experienced an injury related to any of the following: slips, trips or falls inside or outside of the home, being struck by a falling or moving object, traffic accident during the HC work shift, handling or transferring a client, a burn or animal bite or scratch. Development of these questions was informed by the results of our focus groups and in-depth interviews, ${ }^{23}$ and the 2007 National Home Health Aide Survey (NHHAS). ${ }^{28}$

Violence: These questions ascertained whether, in the past 12 months, the aide had experienced any of the following by a client or client's family: physical violence including aggressive physical contact (pinched, scratched, slapped, punched), being bitten or spit on, objects or bodily fluids thrown at them, beaten or strangled, sexual assault; or verbal violence including verbal threat of harm, made to feel bad about oneself, racist language or racial, ethnic, religious or other personal insults, being yelled at or spoken to in an angry or humiliating tone. These questions were adapted from the 2007 NHAAS $^{28}$ and our focus groups and in-depth interviews. ${ }^{23}$

\section{Part two, hazard measures}

The questions in part two mainly were comprised of checklists of hazards or conditions identified in our earlier survey of sharps injuries, ${ }^{2425}$ our focus groups and in-depth interviews, ${ }^{23}$ the 2007 NHAAS $^{28}$ and other HC literature. ${ }^{12} 29$

\section{Survey population recruitment and administration}

Agencies in eastern Massachusetts were identified via the main $\mathrm{HC}$ aide industry association and were representative of both the $\mathrm{HC}$ aide and the $\mathrm{HC}$ client populations in that they were from a variety of locations (urban, suburban, rural) and served a range of racial/ethnic populations. The labour union represented all $\mathrm{HC}$ aides (approximately 34000 ) who were directly hired by clients receiving public assistance for healthcare or social services in Massachusetts. ${ }^{30}$ The survey was administered to the subset of all client-hired aides in the greater Boston area, which includes the largest and most socially and economically diverse groups of clients and aides in Massachusetts.

Main criteria for survey participation were age of at least 18 years and performance of direct client $\mathrm{HC}$ within 1 month of the time of survey administration. The vast majority of agency-hired aides received the questionnaire from the research team as part of an onsite professional training event organised by their employers. The topics of these trainings were unrelated to $\mathrm{OSH}$ or the survey. Participation was voluntary and agency managers were not present while the aides took the survey. Most questionnaires were completed by the agency-hired aides at these sessions and collected by a research team member. A small portion of agency-hired aides who could not attend the training sessions were sent the questionnaire and returned it via postal mail. Postal mail was the only way to reach the client-hired aides because they do not meet in large groups. The research team prepared the questionnaire packages and the union mailed these to members' homes. All questionnaires completed by client-hired aides were returned via postal mail. All aides completed an informed consent form and were given a $\$ 20$ stipend for completing the survey. A total of 2826 questionnaires were distributed to client-hired and agency-hired aides during September 2012-April 2013.

\section{Statistical analyses}

Questionnaires were coded and scanned into an Access database. Proportions of responses to specific questions (with 95\% CIs) were calculated by aides or by client visits using SAS statistical software (V.9.2, SAS Institute Inc, Cary, North Carolina, USA). The proportions of aides hired either via agencies or directly by clients were compared using the difference of two binomial proportions test, with a $\mathrm{p}$ value testing the null hypothesis of equal proportions.

\section{RESULTS}

\section{Demographic and occupational characteristics}

A total of 1255 questionnaires were returned, of which six were rejected for not meeting inclusion criteria. Agency-hired aides completed 634 surveys yielding a response rate of $84 \%$, while the client-hired aides returned 621 surveys yielding a response rate of $30 \%$. The final study population consisted of 1249 aides who returned completed questionnaires, 634 of whom were agency-hired and 615 client-hired (table 1).

The study population was predominantly women. Among men, a higher proportion was client-hired aides (21\% men) versus agency-hired aides (5\% men). The mean age (47 years) was similar between the agency-hired and client-hired aides, and it is notable that more than $40 \%$ were 50 years or older. More than one-third were born outside the US. The agency-hired aides had longer tenure with their current HC employer, 26\% were employed for greater than or equal to 10 years compared to $10 \%$ of client-hired aides. This finding is consistent with the different work organisational structures: agency-hired aides can be reassigned by their employer after a client leaves HC, while client-hired aides must find a new employer. The population was more racially and ethnically diverse than the general Massachusetts and US populations: only 39\% of aides selfidentified as white versus $84 \%$ of the Massachusetts population and $78 \%$ of the US population. ${ }^{31}$ Thirty-eight percent selfidentified as black versus $8 \%$ in Massachusetts and 13\% in the USA, ${ }^{31}$ and client-hired aides were more than twice as likely to be black than agency-hired aides (58\% vs $22 \%$, respectively). The percentage of aides identifying as Asian (4\%) was similar to the Massachusetts and US populations (approximately 5\% in each). The percentage of HC aides reporting Hispanic or Latino ethnicity was $17 \%$, higher than in Massachusetts (9.6\%) yet similar to the general US population (16\%).

The HC population comprised seven occupational titles, with the majority working as personal care attendants (the main title for client-hired aides), home health aides (the main title for agency-hired aides), personal care home makers or homemakers. A greater percentage of agency-hired aides (90\%) earned some type of professional certification relevant to $\mathrm{HC}$ work, including Certified Nurse Assistant (CNA) or Certified Home Health Aide, compared to client-hired aides (37\%). On average, the aides conducted nearly 10 visits per week, more for the agencyhired aides (13.4 visits per week) versus the client-hired aides (5.6 per week). While the client-hired aides had fewer visits, their visits tended to be longer and so the average number of hours worked per week was similar for agency-hired versus client-hired aides (25.8 and $25.3 \mathrm{~h}$ per week, respectively).

\section{Home environmental conditions}

Table 2 shows the percentages of home environmental hazards that occurred during the $3484 \mathrm{HC}$ visits. Several of these are discussed below; one surprising finding is notable: aides reported clients smoking indoors during $10 \%$ of all $\mathrm{HC}$ visits and about 
Table 1 Safe home care survey population characteristics

\begin{tabular}{|c|c|c|c|c|c|c|}
\hline & All aides, $n=1249$ & & Agency-hired aides, & $=634$ & Client-hired aides, & \\
\hline & $\mathbf{n}$ & Per cent & $\mathbf{n}$ & Per cent & $\mathbf{n}$ & Per cent \\
\hline \multicolumn{7}{|l|}{ Age } \\
\hline$<40$ & 374 & 30 & 155 & 24 & 219 & 36 \\
\hline $40-50$ & 295 & 24 & 166 & 26 & 129 & 21 \\
\hline $50-60$ & 350 & 28 & 180 & 28 & 170 & 28 \\
\hline$>60$ & 203 & 16 & 118 & 19 & 85 & 14 \\
\hline Not reported & 27 & 2 & 15 & 2 & 12 & 2 \\
\hline \multicolumn{7}{|l|}{ Gender } \\
\hline Female & 1086 & 87 & 602 & 95 & 484 & 79 \\
\hline Male & 159 & 13 & 31 & 5 & 128 & 21 \\
\hline Not reported & 4 & 0 & 1 & 0 & 3 & 0 \\
\hline \multicolumn{7}{|l|}{ Nativity } \\
\hline Born in US & 765 & 61 & 360 & 57 & 405 & 66 \\
\hline Born outside US & 462 & 37 & 258 & 41 & 204 & 33 \\
\hline Not reported & 22 & 2 & 16 & 3 & 6 & 1 \\
\hline \multicolumn{7}{|l|}{ Race } \\
\hline White & 482 & 39 & 367 & 58 & 115 & 19 \\
\hline Black & 480 & 38 & 137 & 22 & 343 & 58 \\
\hline American Indian/Alaskan native & 6 & 0 & 3 & 0 & 3 & 0 \\
\hline Asian & 56 & 4 & 33 & 5 & 23 & 4 \\
\hline Mixed & 37 & 3 & 13 & 2 & 24 & 4 \\
\hline Not reported & 188 & 15 & 81 & 13 & 107 & 17 \\
\hline \multicolumn{7}{|l|}{ Hispanic/Latino ethnicity } \\
\hline Yes & 214 & 17 & 110 & 17 & 104 & 17 \\
\hline No & 983 & 79 & 492 & 78 & 491 & 80 \\
\hline Not reported & 52 & 4 & 32 & 5 & 20 & 3 \\
\hline \multicolumn{7}{|l|}{ Preferred language } \\
\hline English & 918 & 74 & 450 & 71 & 468 & 76 \\
\hline Spanish & 123 & 10 & 65 & 10 & 58 & 9 \\
\hline Other* & 203 & 16 & 117 & 18 & 86 & 14 \\
\hline \multicolumn{7}{|l|}{ Occupation (usual)†‡ } \\
\hline Personal care attendant & 539 & 43 & 72 & 11 & 467 & 76 \\
\hline Home health aide & 360 & 29 & 271 & 43 & 89 & 14 \\
\hline Personal care homemaker & 358 & 29 & 243 & 38 & 115 & 19 \\
\hline Homemaker & 227 & 22 & 230 & 36 & 47 & 8 \\
\hline Certified nursing assistant & 112 & 9 & 74 & 12 & 38 & 6 \\
\hline Companion & 103 & 8 & 71 & 11 & 32 & 5 \\
\hline Hospice aide & 33 & 3 & 20 & 3 & 13 & 2 \\
\hline Any home care relevant professional certification§ & 800 & 64 & 572 & 90 & 228 & 37 \\
\hline \multicolumn{7}{|l|}{ Tenure with current employer } \\
\hline$<2$ years & 369 & 29 & 172 & 27 & 197 & 32 \\
\hline $2-9$ years & 608 & 49 & 275 & 43 & 333 & 54 \\
\hline$\geq 10$ years & 226 & 18 & 164 & 26 & 62 & 10 \\
\hline Not reported & 46 & 4 & 23 & 4 & 23 & 4 \\
\hline \multicolumn{7}{|l|}{ Measures of work load (mean, SD, IQR) } \\
\hline Visits in the past week & $9.6,9.7,3-13$ & & $13.4,10.5,6-20$ & & $5.6,7.0,1-7$ & \\
\hline Hours worked per week in home care & $25.5,15.3,15-30$ & & $25.8,14.0,15-30$ & & $25.3,16.7,15-30$ & \\
\hline
\end{tabular}

$10 \%$ of the visits involved a patient on oxygen. We discuss the hazards of smoking and home oxygen use elsewhere. ${ }^{32}$

\section{Infectious agents, cleaning and disinfecting chemical use}

Contact with blood occurred in 5\% of the $3484 \mathrm{HC}$ visits (table 2); $3 \%$ of HC visits involved working in homes where the aide reported that used sharps were left lying around without safe storage. Aides helped a client use a sharp in $4 \%$ of the HC visits overall, with the practice occurring more frequently during client-hired aide visits than agency-hired aide visits $(11.8 \%$ vs $1.6 \%$ respectively, $\mathrm{p}<0.001)$. Contact with faeces occurred in $13 \%$ of the agency-hired aide visits and $24 \%$ of the client-hired aide visits $(\mathrm{p}<0.001)$. The great majority of $\mathrm{HC}$ aide visits involved cleaning and disinfecting bathrooms and 
Table 2 OSH hazards reported by home care aides in the safe home care survey

\begin{tabular}{|c|c|c|c|c|c|c|c|c|c|c|}
\hline & \multicolumn{3}{|c|}{ All aides, $n=3484$} & \multicolumn{3}{|c|}{ Agency-hired aides, $n=2564$} & \multicolumn{3}{|c|}{ Client-hired aides, $n=920$} & \multirow[b]{2}{*}{ p Value* } \\
\hline & $\mathbf{n}$ & Per cent & $95 \% \mathrm{Cl}$ & $\mathbf{n}$ & Per cent & $95 \% \mathrm{Cl}$ & $\mathrm{n}$ & Per cent & $95 \% \mathrm{Cl}$ & \\
\hline \multicolumn{11}{|l|}{ Home environment } \\
\hline No access to equipment to move client & 1325 & 38 & (36.4 to 39.6 ) & 1011 & 39.4 & (37.5 to 41.3 ) & 314 & 34.1 & (31.1 to 37.2 ) & 0.004 \\
\hline Cluttered or unclean conditions & 593 & 17 & (15.8 to 18.3$)$ & 467 & 18.2 & (16.7 to 19.7$)$ & 126 & 13.7 & (11.5 to 15.9$)$ & 0.002 \\
\hline Slippery floors & 197 & 5.6 & (4.9 to 6.4 ) & 150 & 5.9 & (4.9 to 6.8$)$ & 47 & 5.1 & (3.7 to 6.5 ) & 0.404 \\
\hline Uncontrolled pets & 127 & 3.6 & (3.0 to 4.3 ) & 89 & 3.5 & (2.8 to 4.2 ) & 38 & 4.1 & (2.8 to 5.4 ) & 0.360 \\
\hline Bedbugs & 86 & 2.5 & (2.0 to 3.0 ) & 51 & 2 & (1.4 to 2.5$)$ & 35 & 3.8 & (2.6 to 5.0 ) & 0.002 \\
\hline Client smokes indoors & 346 & 9.9 & (8.9 to 10.9 ) & 238 & 9.3 & (8.2 to 10.4 ) & 108 & 11.7 & (9.7 to 13.8 ) & 0.033 \\
\hline Client on oxygen & 314 & 9 & (8.1 to 10.0$)$ & 218 & 8.5 & (7.4 to 9.6$)$ & 96 & 10.4 & (8.5 to 12.4$)$ & 0.079 \\
\hline \multicolumn{11}{|c|}{ Infectious agents, cleaning and disinfecting chemical use } \\
\hline Used sharps lying around homet & 110 & 3.2 & (2.6 to 3.7$)$ & 66 & 2.6 & (2.0 to 3.2$)$ & 44 & 4.8 & (3.4 to 6.2 ) & 0.001 \\
\hline Helped someone use a sharp $\dagger$ & 149 & 4.3 & (3.6 to 5.0$)$ & 40 & 1.6 & (1.1 to 2.0$)$ & 109 & 11.8 & (9.8 to 13.9$)$ & $<0.001$ \\
\hline Contact with faeces & 563 & 16.2 & (14.9 to 17.4$)$ & 339 & 13.2 & (11.9 to 14.5$)$ & 224 & 24.3 & (21.6 to 27.1$)$ & $<0.001$ \\
\hline Contact with blood & 176 & 5 & (4.3 to 5.8 ) & 111 & 4.3 & (3.5 to 5.1 ) & 65 & 7.1 & (5.4 to 8.7 ) & 0.001 \\
\hline Client had an infectious disease & 119 & 3.4 & (2.8 to 4.0$)$ & 85 & 3.3 & (2.7 to 4.1$)$ & 34 & 3.7 & (2.5 to 4.9 ) & 0.586 \\
\hline Contact with pet waste & 357 & 10.2 & (9.2 to 11.2$)$ & 178 & 6.9 & (6.0 to 8.0$)$ & 179 & 19.5 & (16.9 to 22.0$)$ & $<0.001$ \\
\hline Cleaned bathroom/kitchen & 2797 & 80.3 & (79.0 to 81.6$)$ & 2057 & 80.2 & (78.7 to 81.8$)$ & 740 & 80.4 & (77.9 to 83.0$)$ & 0.892 \\
\hline Cleaned with bleach & 828 & 23.8 & (22.4 to 25.2 ) & 518 & 20.2 & (18.6 to 21.8 ) & 310 & 33.7 & (30.6 to 36.8$)$ & $<0.001$ \\
\hline Cleaned with ammonia & 266 & 7.6 & (6.8 to 8.5$)$ & 145 & 5.7 & (4.8 to 6.6$)$ & 121 & 13.2 & (11.0 to 15.3$)$ & $<0.001$ \\
\hline Cleaned with other strong chemicals & 530 & 15.2 & $(14.0$ to 16.4$)$ & 362 & 14.1 & (12.8 to 15.5 ) & 168 & 18.3 & (15.8 to 20.8 ) & 0.003 \\
\hline Any bleach/ammonia/chemical use & 1046 & 30 & (28.5 to 31.5 ) & 692 & 27 & (25.3 to 28.7 ) & 354 & 38.5 & (35.3 to 41.6$)$ & $<0.001$ \\
\hline
\end{tabular}

Per cent of home care visits $(n=3484)$ in which an OSH hazard occurred.

${ }^{*}$ Test of $\mathrm{H}_{0}$ : no difference in the percentage of OSH hazard reported by agency-hired versus client-hired aides.

†A 'sharp' is a sharp medical device capable of penetrating the skin and contacting blood, such as a syringe with a needle or a lancet.

OSH, Occupational Safety and Health.

kitchens ( $80 \%$ of $\mathrm{HC}$ visits). Bleach was the most commonly used disinfectant (20\% for agency-hired aide visits and $34 \%$ for client-hired aide visits, $\mathrm{p}<0.001)$. Ammonia and other strong cleaning chemicals also were used.

\section{Musculoskeletal injuries and hazards}

Table 3 summarises the aides $(n=1249)$ survey responses regarding their experience of pain or injuries occurring in the past
12 months that were severe enough to result in lost work time or the need for medical care. Based on this definition, more than $10 \%$ of the aides experienced some type of work-related injury in the past 12 months. Of these, the most common was a musculoskeletal injury related to client handling, followed by slips, trips or falls outside home. About one-third of all aides experienced back pain in the past 12 months and about onefourth of this group considered the pain to be work-related and

Table 3 Injuries in the past 12 months reported by home care aides $(n=1249)$ in the safe home care survey

\begin{tabular}{|c|c|c|c|c|c|c|c|c|c|c|}
\hline & \multicolumn{3}{|c|}{ All aides, $n=1249$} & \multicolumn{3}{|c|}{ Agency-hired aides, $n=634$} & \multicolumn{3}{|c|}{ Client-hired aides, $n=615$} & \multirow[b]{2}{*}{ p Value* } \\
\hline & $\mathrm{n}$ & Per cent & $95 \% \mathrm{Cl}$ & $\mathbf{n}$ & Per cent & $95 \% \mathrm{Cl}$ & $\mathbf{n}$ & Per cent & $95 \% \mathrm{Cl}$ & \\
\hline \multicolumn{11}{|c|}{ Work-related injuries resulting in lost worktime or medical care } \\
\hline Any work-related injury & 140 & 11.2 & (9 to 13 ) & 86 & 13.6 & (10.9 to 16.2$)$ & 54 & 8.8 & (6.5 to 11.0$)$ & 0.007 \\
\hline Client handling injury & 24 & 1.9 & (1.2 to 2.7 ) & 9 & 1.4 & (0.5 to 2.3 ) & 15 & 2.4 & (1.2 to 3.7 ) & 0.195 \\
\hline Slip, trip, fall outside home & 22 & 1.8 & (1.0 to 2.5$)$ & 12 & 1.9 & (0.8 to 3.0$)$ & 10 & 1.6 & (0.6 to 2.6 ) & 0.686 \\
\hline Slip, trip, fall inside home & 16 & 1.3 & (0.7 to 1.9$)$ & 10 & 1.6 & (0.6 to 2.6 ) & 6 & 1 & (0.2 to 1.8$)$ & 0.350 \\
\hline Traffic accident & 16 & 1.3 & (0.7 to 1.9$)$ & 9 & 1.4 & (0.5 to 2.3 ) & 7 & 1.1 & (0.3 to 2.0$)$ & 0.634 \\
\hline Burn & 8 & 0.6 & ( 0.2 to 1.1$)$ & 3 & 0.5 & (0 to 1.0$)$ & 5 & 0.6 & (0.1 to 1.5$)$ & 0.811 \\
\hline All other work-related injuries & 14 & 1.1 & (0.5 to 1.7$)$ & 8 & 1.3 & (0.4 to 2.1$)$ & 6 & 1 & (0.2 to 1.8 ) & 0.619 \\
\hline \multicolumn{11}{|l|}{ Back Pain } \\
\hline Any back pain & 420 & 33.6 & (31.0 to 36.2 ) & 201 & 31.2 & (28.1 to 35.3 ) & 219 & 35.6 & (31.8 to 39.4 ) & 0.099 \\
\hline At least once/week & 249 & 19.9 & (17.7 to 22.2 ) & 110 & 17.4 & (14.4 to 20.3$)$ & 139 & 22.6 & (19.3 to 25.9$)$ & 0.022 \\
\hline Requiring medication & 285 & 22.8 & (20.0 to 25.2 ) & 131 & 20.7 & (17.5 to 23.8$)$ & 154 & 25 & (21.6 to 28.5 ) & 0.070 \\
\hline Pain considered work related & 320 & 25.6 & (23.2 to 28.0 ) & 147 & 23.2 & (19.9 to 26.5$)$ & 173 & 28.1 & (24.6 to 31.7 ) & 0.318 \\
\hline \multicolumn{11}{|l|}{ Sharps injuries } \\
\hline At least one needlestick or other sharps injurył’ $¥$ & 23 & 1.8 & (1.1 to 2.6$)$ & 12 & 1.9 & (0.8 to 3.0$)$ & 11 & 1.8 & (0.7 to 2.8$)$ & 0.896 \\
\hline
\end{tabular}


required medication to manage this pain. Aides reported more than one-third of their visits lacked safe patient handling equipment for client mobility (table 2). This lack was somewhat more pronounced for agency-hired aides visits than for client-hired aides visits (39\% vs 34\% respectively, $\mathrm{p}=0.004)$.

\section{Violence}

In presurvey focus groups, aides reported experiences of violence on the job. ${ }^{23}$ In this survey we quantified the percentages of aides $(n=1249)$ who experienced some form of violence during a $\mathrm{HC}$ visit in the past 12 months prior to the survey (table 4). Approximately $7 \%$ of the aides reported an experience of physical violence while nearly $20 \%$ experienced verbal violence. The agency-hired aides reported verbal violence more frequently than client-hired aides $(23 \%$ vs $14 \%$ respectively, $\mathrm{p}<0.001)$.

\section{Job satisfaction, job security and safety climate}

All aides reported high percentages of agreement with measures of job satisfaction (table 5). A majority reported enjoyment of caring for others, ability to work independently, and flexible work schedules as main reasons for continuing in their current job, with agency-hired aides reporting somewhat higher satisfaction. Approximately two-thirds agreed that their job is stable and do not fear losing it. Less than half agreed that there are good opportunities for promotion and professional advancement. In general, client-hired aides reported poorer safety climate than agency-hired aides, particularly in relation to being taken seriously if they reported disrespect $(71 \%$ of client-hired aides vs $88 \%$ agency-hired aides, $\mathrm{p}<0.001)$; believing that the client's care comes before their safety (37\% of client-hired aides vs $28 \%$ of agency-hired aides, $\mathrm{p}<0.001$ ); and knowing how to report sharps injuries $(70 \%$ of client-hired aides vs $88 \%$ of agency-hired aides, $\mathrm{p}<0.001)$. Agency-hired aides were more frequently asked by their clients to perform activities that are not part of their job (52\% for agency-hired aides vs $28 \%$ for client-hired aides, $\mathrm{p}<0.001)$.

\section{DISCUSSION}

This was one of the largest and most detailed investigations of the $\mathrm{OSH}$ of $\mathrm{HC}$ aides to date. The results show that $\mathrm{HC}$ aides experience a wide range of OSH hazards, which are commonly found in healthcare institutions such as hospitals and long-term care facilities. ${ }^{33}$ We quantified the occurrence of these hazards and compared them between two major categories of aides, those hired by agencies versus those hired directly by clients. We found that client-hired and agency-hired aides have relatively similar OSH experiences with a few exceptions, including use of sharps and experience of verbal violence.

The main limitation was the difference in response rates for the two categories of aides. The response rate for returning the questionnaire was higher for the agency-hired aides (84\%) than for the client-hired aides (30\%). This difference was expected and is mainly attributable to the different survey administration methods. Agency-hired aides were primarily contacted in-person at mandatory agency in-service training sessions while the only way to reach client-hired aides was by postal mail with the collaboration of their union. It is possible that the lower response rate for client-hired aides introduced some bias and care should be taken in attributing differences in survey responses between the two groups of aides. To follow-up on this concern, we presented the survey results to focus groups of both types of aides and to industry and labour leaders using in-depth interviews. None of the differences between the two aides' categories was surprising to those respondents and useful interpretations of the findings were offered based on HC professional experiences.

\section{Musculoskeletal injuries and hazards}

The musculoskeletal injuries and hazards reported by the $\mathrm{HC}$ aides are similar to those reported by aides in nursing homes $^{26} 27$ and hospitals. ${ }^{33}$ Effective interventions have been developed to improve work-related musculoskeletal health in institutional healthcare settings and these should be evaluated for adaptation in HC. Improvements in occupational musculoskeletal health can have positive impacts on client safety and continuity of care as well as on aides' OSH. For example, many $\mathrm{HC}$ aides are so dedicated to their clients that they try to

Table 4 Experience of violence from a client or family member in the past 12 months reported by home care aides $(n=1249)$ in the safe home care survey

\begin{tabular}{|c|c|c|c|c|c|c|c|c|c|c|}
\hline & \multicolumn{3}{|c|}{ All aides, $n=1249$} & \multicolumn{3}{|c|}{ Agency-hired aides, n=634 } & \multicolumn{3}{|c|}{ Client-hired aides, $n=615$} & \multirow[b]{2}{*}{ p Value* } \\
\hline & $\mathrm{n}$ & Per cent & $95 \% \mathrm{Cl}$ & $\mathrm{n}$ & Per cent & $95 \% \mathrm{Cl}$ & $\mathbf{n}$ & Per cent & $95 \% \mathrm{Cl}$ & \\
\hline \multicolumn{11}{|l|}{ Physical violence } \\
\hline Any physical violencet & 82 & 6.6 & (5.2 to 7.9 ) & 50 & 7.9 & (5.8 to 10.0$)$ & 32 & 5.2 & (3.4 to 7.0 ) & 0.054 \\
\hline Aggressive physical contact & 61 & 4.9 & (3.7 to 6.1 ) & 37 & 5.8 & (4.0 to 7.7 ) & 24 & 3.9 & (2.4 to 5.4$)$ & 0.119 \\
\hline Objects thrown & 28 & 2.2 & (1.4 to 3.1$)$ & 20 & 3.2 & (1.8 to 4.5$)$ & 8 & 1.3 & (0.4 to 2.2 ) & 0.024 \\
\hline Sexual assault & 9 & 0.7 & (0.2 to 1.2$)$ & 5 & 0.8 & (0.1 to 1.5$)$ & 4 & 0.6 & (0 to 1.3 ) & 0.672 \\
\hline Bitten or spit on & 17 & 1.4 & (0.7 to 2.0$)$ & 9 & 1.4 & (0.5 to 2.3$)$ & 8 & 1.3 & (0.4 to 2.2 ) & 0.878 \\
\hline Bodily fluids thrown & 8 & 0.6 & (0.2 to 1.1$)$ & 3 & 0.5 & (0 to 1.0$)$ & 5 & 0.8 & (0.1 to 1.5$)$ & 0.509 \\
\hline Beaten or strangled & 2 & 0.2 & (0 to 0.4 ) & 1 & 0.2 & (0 to 0.5$)$ & 1 & 0.2 & (0.1 to 0.4$)$ & 1.000 \\
\hline \multicolumn{11}{|l|}{ Verbal violence } \\
\hline Any verbal violence & 235 & 18.8 & (16.6 to 21.0$)$ & 147 & 23.2 & (19.9 to 26.5 ) & 88 & 14.3 & (11.5 to 17.1$)$ & $<0.001$ \\
\hline Yelled at & 186 & 14.9 & (12.9 to 16.9$)$ & 115 & 18.1 & (15.1 to 21.1$)$ & 71 & 11.5 & (9.0 to 14.1 ) & 0.001 \\
\hline Made to feel bad about self & 106 & 8.5 & (6.9 to 10.0$)$ & 68 & 10.7 & (8.3 to 13.1$)$ & 38 & 6.2 & (4.3 to 8.1 ) & 0.004 \\
\hline Racist language & 60 & 4.8 & (3.6 to 6.0 ) & 44 & 6.9 & (5.0 to 8.9 ) & 16 & 2.6 & (1.3 to 3.9 ) & $<0.001$ \\
\hline Verbal threat of harm & 52 & 4.1 & (3.1 to 5.3 ) & 35 & 5.5 & (3.7 to 7.3 ) & 17 & 2.8 & (1.5 to 4.1$)$ & 0.017 \\
\hline
\end{tabular}


Table 5 Work organisational characteristics reported by home care aides $(n=1249)$ in the safe home care survey

\begin{tabular}{|c|c|c|c|c|c|c|c|}
\hline & \multirow{2}{*}{\multicolumn{2}{|c|}{$\begin{array}{l}\text { All Aides } n=1249 \\
\text { Agree }\end{array}$}} & \multirow{2}{*}{\multicolumn{2}{|c|}{$\begin{array}{l}\text { Agency-hired } \\
\text { aides } n=634 \\
\text { Agree }\end{array}$}} & \multirow{2}{*}{\multicolumn{2}{|c|}{$\begin{array}{l}\text { Client-hired aides } \\
\mathrm{n}=615\end{array}$}} & \multirow[b]{3}{*}{ p Value* } \\
\hline & & & & & & & \\
\hline & $\mathbf{n}$ & Per cent & $\mathbf{n}$ & Per cent & $\mathbf{n}$ & Per cent & \\
\hline \multicolumn{8}{|l|}{ Job satisfaction } \\
\hline I get the respect I deserve & 1064 & 85.2 & 549 & 86.6 & 515 & 83.7 & 0.149 \\
\hline My work contributes to improving client's health & 1117 & 89.4 & 574 & 90.5 & 543 & 88.3 & 0.206 \\
\hline I would recommend this job to a friend & 1094 & 87.6 & 562 & 88.6 & 532 & 86.5 & 0.261 \\
\hline I probably or definitely will NOT leave my job & 1035 & 82.9 & 540 & 85.2 & 495 & 80.5 & 0.028 \\
\hline I continue to work in my current job because: & - & & - & & - & & \\
\hline I enjoy caring for others & 1069 & 85.6 & 572 & 90.2 & 497 & 80.8 & $<0.001$ \\
\hline I have a flexible work schedule & 781 & 62.5 & 420 & 66.2 & 361 & 58.7 & 0.006 \\
\hline I can work independently & 747 & 59.8 & 396 & 62.5 & 351 & 57.1 & 0.052 \\
\hline \multicolumn{8}{|l|}{ Job Security } \\
\hline I have a stable job, I'm not afraid of losing it & 816 & 65.3 & 431 & 68.0 & 385 & 62.6 & 0.045 \\
\hline I have good opportunities for promotion/professional development & 571 & 45.7 & 310 & 48.9 & 261 & 42.2 & 0.018 \\
\hline My hours are predictable, usually the same week to week & 859 & 68.8 & 377 & 59.5 & 482 & 78.4 & $<0.001$ \\
\hline \multicolumn{8}{|l|}{ Safety climate } \\
\hline My employer considers my health and safety important & 1128 & 90.3 & 598 & 94.3 & 530 & 86.2 & $<0.001$ \\
\hline I would be taken seriously if I reported disrespect & 998 & 79.9 & 559 & 88.2 & 439 & 71.4 & $<0.001$ \\
\hline Clients ask me to do things that are not part of my job & 502 & 40.2 & 330 & 52.0 & 172 & 28.0 & $<0.001$ \\
\hline I believe client care comes before my safety & 403 & 32.3 & 175 & 27.6 & 228 & 37.1 & $<0.001$ \\
\hline I get enough information on client's health to protect myself & 984 & 78.8 & 484 & 76.3 & 500 & 81.3 & 0.031 \\
\hline I know how to report sharps injuries & 989 & 79.2 & 560 & 88.3 & 429 & 69.8 & $<0.001$ \\
\hline
\end{tabular}

perform their work despite having musculoskeletal injuries. ${ }^{23}$ Safe client mobility will be more difficult if a $\mathrm{HC}$ aide has back strain, especially if, as in about $40 \%$ of the $\mathrm{HC}$ visits in this study, no equipment is available to assist with client mobility.

The next most frequent injury was related to 'slips, trips, and falls'. These survey results support the presurvey interviews with two insurance company representatives which indicated that back and shoulder injuries were the most frequently reported injuries in HC and these often resulted in costly workers' compensation claims. $^{23}$

\section{Infection hazards and infection prevention}

Client-hired aides reported helping a client use a sharp, such as a needle or lancet, seven times more often than agency-hired aides (table 2) and fewer client-hired aides reported knowing how to report a sharps injury (table 5). Agency-hired aides who are supervised by nurses are instructed not to use sharps. The close client relationship can make it more difficult for an aide to resist the pressure to perform work that is outside of the care plan, for example, performing a medical procedure for the client with a sharp, such as for diabetes management or vitamin injections. Another study by the research team identified the two major pathways sharps enter the home, by home healthcare clinicians and by home users. Interviews with home users frequently cited lack of sharps with injury prevention features, reuse of sharps, and challenges in sharps disposal practices. ${ }^{34}$

The great majority $(80 \%)$ of $\mathrm{HC}$ aides' visits involved cleaning bathrooms and kitchens in order to prevent infections. ${ }^{35}$ Infection is a serious risk in $\mathrm{HC}$, and cleaning and disinfecting is important for infection prevention; however, some common cleaning chemicals can also introduce respiratory hazards. ${ }^{36} 37$ Further research on safe and effective infection prevention practices in HC is needed.

\section{Violence}

The results show that agency-hired aides experienced more verbal violence during their visits than client-hired aides (table 4). The focus groups and interviews provided insights on this topic. First, we were told that agency-hired aides are encouraged to report aggressive behaviours to their supervisors who then follow-up with an appropriate intervention. ${ }^{23}$ Second, agency-hired aides are more frequently assigned to clients with dementia as well as to new clients in new HC situations. ${ }^{23}$ Aides attending focus groups explained that the risk of violent behaviour is higher when a client or family member has dementia or when the client's living conditions change leading to the client feeling uncertain or fearful. Training and other interventions on how to report and protect oneself from physical, verbal and sexual violence need to continue for all types of aides, and should be customised depending on the work organisation of the aide.

These study findings provide a comprehensive overview of the $\mathrm{OSH}$ experience of $\mathrm{HC}$ aides. The data contradict a prevalent perception that the work of $\mathrm{HC}$ aides is less demanding than other forms of employment and the implicit assumption that there are few OSH hazards. This perception may arise in part because the home is not recognised as a workplace, caregiving is not valued as highly as other work, and HC aides are predominantly female, with low-income and increasingly from minority populations. ${ }^{38} \mathrm{HC}$ aides are not entitled to the basic minimum wage and overtime protections that most employees in the USA are guaranteed under the Fair Labour Standard Act (FLSA). ${ }^{39}$ Their work, deemed 'companionship services', is one of the few employment categories exempted from the FLSA. However, some states, including Massachusetts, require that both minimum wage and overtime be paid to employees performing these companionship services. 
A major strength of this study was the research team's partnership with HC agencies and a union to develop effective methods to assess a large population of HC aides. HC aides are difficult to reach because they seldom gather in an office or other work location, they work alone, are geographically dispersed and have very limited time outside of work because many also care for their own family members.

The first part of the questionnaire used the individual aide as the unit of analysis, a standard format for OSH surveys, while the second part used an innovative design with the $\mathrm{HC}$ visit as the unit of analysis. This combination allowed us to evaluate both rare and severe events, such as needle-sticks, as well as less severe events that occur in nearly every visit such as exposure to cleaning chemicals. Several studies have quantified specific hazards among HC aides such as musculoskeletal injuries, ${ }^{9} 11$ violence, ${ }^{13}$ blood-borne pathogen exposures ${ }^{12} 151625$ and psychosocial stress, ${ }^{10}{ }^{14}$ but to our knowledge, none have calculated these risks per visit. In HC, the visit is the standard measure of productivity and for budget calculations and it is the unit of care delivery. The detailed information gathered on the aides' most recent visits allowed us to estimate risks of hazardous conditions that are highly variable from client- to-client throughout the work day. Assuming our data were approximately unbiased, the results can be applied to projections about the numbers of hazardous events experienced by aides in the state or nationally.

Owing to resource limitations, this survey was conducted in English only. As a condition of employment, agency-hired aides are required to pass a test on basic English reading and writing proficiency. Client-hired aides usually have some English proficiency but there is no systematic testing for them, and their English proficiency may be more limited. This may have contributed to the lower response rate for the client-hired aides in this study. Future surveys should be conducted in multiple languages.

Another potential limitation was the use of a 12-month recall period for some outcomes, including needle-stick injuries, traffic accidents, slips trips and falls and serious low back pain. The 12 -month recall is a standard time period for OSH surveys and was used in the one US national HC aide survey that has been published. ${ }^{28}$ It is possible that the recall of injuries decreased with time over the course of the year but, if so, the true frequency of injuries would likely have been higher. ${ }^{40}$

All of the HC agencies in our study expressed a strong commitment to improving OSH. Even so, the HC agencies and governmental organisations which enforce OSH regulations cannot always control the hazards that occur in private homes. A fundamental policy dialogue is warranted to address this gap. At the same time agencies, unions, trade associations, government organisations, clients and families must partner to promote safe conditions that will benefit aides and clients alike.

Acknowledgements The Safe Home Care Project research team members are grateful to the home care agencies, trade associations, labour unions, public health professionals and other participants who contributed to this study. A special thanks to all home care aides, nurses and other caregivers who enrich so many lives.

Contributors MMQ, PKM, CJG, SRS, DK, AKL and LD designed the study. All authors contributed to the development of the questionnaire and implementation of the methods. MMQ, PKM, CJG, SRS, NMB, DO, CS and AKL collected the data. $M M Q, R J G, D K, N M B, D O, C S$ and $L P$ analysed the data. MMQ drafted the manuscript and all authors reviewed the manuscript and provided substantive contributions.

Funding This study was funded by the US National Institute for Occupational Safety and Health (NIOSH) (R01 OH008229).

Competing interests None declared.
Ethics approval University of Massachusetts Lowell (UML) USA Institutional Review Board (IRB).

Provenance and peer review Not commissioned; externally peer reviewed.

Open Access This is an Open Access article distributed in accordance with the Creative Commons Attribution Non Commercial (CC BY-NC 4.0) license, which permits others to distribute, remix, adapt, build upon this work non-commercially, and license their derivative works on different terms, provided the original work is properly cited and the use is non-commercial. See: http://creativecommons.org/ licenses/by-nc/4.0/

\section{REFERENCES}

1 U.S. National Institute on Aging, National Institute of Health. Why population aging matters: a global perspective. 2007. http://www.nia.nih.gov/sites/default/files/ WPAM.pdf (accessed 15 Jun 2015).

2 National Research Council. Health care comes home: the human factors Washington DC: The National Academies Press, 2011. http://www.nap.edu/catalog/ 13149/health-care-comes-home-the-human-factors (accessed 15 Jun 2015)

3 Bureau of Labor Statistics. Employment projections: fastest growing occupations. Washington DC: U.S. Department of Labor, 2013. http://www.bls.gov/emp/ep_ table_103.htm (accessed 15 Jun 2015).

4 Genet N, Boerma W, Kroneman M, et al. Home care across Europe: current structure and future challenges. The European Observatory on Health Systems and Policies, World Health Organization, 2012. http://www.euro.who.int/_data/assets/ pdf_file/0008/181799/e96757.pdf?ua=1 (accessed 15 Jun 2015).

5 Tarricone R, Tsouros AD. The solid facts: home care in Europe. Bocconi University, Italy: The Regional Office for Europe of the World Health Organization, 2008. http:// www.euro.who.int/_data/assets/pdf_file/0005/96467/E91884.pdf?ua=1 (accessed 15 Jun 2015)

6 Bureau of Labor Statistics. Occupational outlook handbook, 2014-15 edition, home health aides. Washington DC: US Department of Labor, 2014. http://www.bls.gov/ ooh/healthcare/home-health-aides.htm (accessed 15 Jun 2015).

7 Bureau of Labor Statistics. Occupational outlook handbook, 2014-15 edition, personal care aides. Washington DC: US Department of Labor, 2014. http://www. bls.gov/ooh/healthcare/personal-care-aides.htm (accessed 15 Jun 2015).

8 Paraprofessional Healthcare Institute. The invisible care gap: caregivers without coverage. Ten key facts. PHI-334 ed. Bronx, NY, 2008. http://www. directcareclearinghouse.org/download/PHI\%20CPS\%20Report\%20May\%2008.pdf (accessed 15 Jun 2015).

9 Wipfli B, Olson R, Wright $\mathrm{R}$, et al. Characterizing hazards and injuries among home care workers. Home Healthc Nurse 2012;30:387-93.

10 Delp L, Wallace SP, Geiger-Brown J, et al. Job stress and job satisfaction: home care workers in a consumer-directed model of care. Health Serv Res 2010;45:922-40.

11 Faucett J, Kang T, Newcomer R. Personal service assistance: musculoskeletal disorders and injuries in consumer-directed home care. Am J Ind Med 2013:56:454-68.

12 Lipscomb J, Sokas R, McPhaul K, et al. Occupational blood exposure among unlicensed home care workers and home care registered nurses: are they protected? Am J Ind Med 2009;52:563-70.

13 McPhaul K, Lipscomb J, Johnson J. Assessing risk for violence on home health visits. Home Healthc Nurse 2010;28:278-89.

14 Bercovitz A, Moss A, Sengupta M, et al. An overview of home health aides: United States, 2007. Natl Health Stat Report 2011;34:1-31.

15 Gershon RR, Pearson JM, Sherman MF, et al. The prevalence and risk factors for percutaneous injuries in registered nurses in the home health care sector. Am J Infect Control 2009;37:525-33.

16 Gershon RRM, Pogorzelska M, Qureshi KA, et al. Home health care patients and safety hazards in the home: preliminary findings. In: Henriksen K, Battles JB, Keyes MA, Grady ML, eds. Advances in patient safety: new directions and alternative approaches (vol. 1: assessment). Rockville, MD, 2008.

17 Home Care Aide Council. Overview of Massachusetts Home Care Aide Career Ladder. 2008. http://www.mahomecareaides.com/documents/MAHomeCareAides.pdf (accessed 15 Jun 2015).

18 Wright B. Direct care workers in long-term care. Public Policy Institute: American Association of Retired Persons (AARP), 2005. http://assets.aarp.org/rgcenter/il/ dd117_workers.pdf (accessed 15 Jun 2015).

19 Smith K, Baughman R. Caring for America's aging population: a profile of the direct-care workforce. Monthly Labor Review, 2007. http://www.bls.gov/opub/mlr/ 2007/09/art3full.pdf (accessed 15 Jun 2015).

20 Seavey D, Marquand A. Caring in America. A comprehensive analysis of the nation's fastest growing jobs: home health and personal care aides. Paraprofessional Healthcare Institute, 2011. http://phinational.org/sites/phinational. org/files/clearinghouse/caringinamerica-20111212.pdf (accessed 15 Jun 2015).

21 Office of the Assistant Secretary for Planning and Evaluation. 2015 poverty guidelines. Washington DC: US Department of Health and Human Services, 2014. http://aspe.hhs.gov/poverty/15poverty.cfm (accessed 15 Jun 2015). 
22 National Institute for Occupational Safety and Health. $r 2 p$ : research to practice at NIOSH. Atlanta, GA: Centers for Disease Control and Prevention, 2011. http://www. cdc.gov/niosh/r2p/ (accessed 15 Jun 2015).

23 Markkanen P, Quinn M, Galligan C, et al. Characterizing the nature of home care work and occupational hazards: a developmental intervention study. Am J Ind Med 2014;57:445-57.

24 Markkanen P, Chalupka S, Galligan C, et al. Studying home health care nurses and aides: research design and challenges. J Res Nurs 2008;13:480-95.

25 Quinn M, Markkanen P, Galligan C, et al. Sharps injuries and other blood and body fluid exposures among home health care nurses and aides. Am J Public Health 2009;99(Suppl 3):S710-17.

26 Kurowski A, Buchholz B, Punnett L. A physical workload index to evaluate a safe resident handling program for nursing home personnel. Hum Factors 2014;56:669-83.

27 Kurowski A, Gore R, Buchholz B, et al. Differences among nursing homes in outcomes of a safe resident handling program. J Healthc Risk Manag 2012;32:35-51.

28 Centers for Disease Control and Prevention. 2007 National Home Health Aide Survey (NHHAS). U.S. Department of Health and Human Services, 2012. http:// www.cdc.gov/nchs/nhhas.htm (accessed 15 Jun 2015).

29 Gershon RR, Dailey M, Magda LA, et al. Safety in the home healthcare sector: development of a new household safety checklist. J Patient Saf 2012;8:51-9.

30 The Personal Care Attendant Quality Home Care Workforce Council. Performance review report to the governor and the general court. 2014. http://www.mass.gov/ pca/docs/annual-review-report-2014.pdf (accessed 15 Jun 2015).

31 Population Division of the U.S. Census Bureau. Annual Estimates of the Resident Population by Sex, Race, and Hispanic Origin for the United States, States, and Counties: April 1, 2010 to July 1, 2013. 2014
32 Galligan CJ, Markkanen PK, Fantasia LM, et al. A growing fire hazard concern in communities: home oxygen therapy and continued smoking habits. New Solut 2015;24:535-54.

33 World Health Organization (WHO). Health Worker Occupational Health (WHO website). 2015. http://www.who.int/occupational_health/topics/hcworkers/en/ (accessed 15 Jun 2015).

34 Markkanen P, Galligan C, Laramie A, et al. Understanding sharps injuries in home healthcare: the safe home care qualitative methods study to identify pathways for injury prevention. BMC Public Health 2015;15:359.

35 Shang J, Larson E, Liu J, et al. Infection in home health care: results from national outcome and assessment information set data. Am J Infect Control 2015;43:454-9.

36 Quinn MM, Henneberger PK. Cleaning and disinfecting environmental surfaces in health care: toward an integrated framework for infection and occupational illness prevention. Am J Infect Control 2015;43:424-34.

37 Casas L, Espinosa A, Borràs-Santos $A$, et al. Domestic use of bleach and infections in children: a multicentre cross-sectional study. Occup Environ Med 2015;72: 602-604.

38 Markkanen P, Quinn M, Sama S. When the home is a workplace: promoting health and safety for a vulnerable work force. In: Duffy M, Armenia A, Stacey CL, eds. Caring on the clock: the complexities and contradictions of paid care work. New Brunswick, NJ: Rutgers University Press, 2015:94-103.

39 U.S. Department of Labor. Fact Sheet \#25: Home Health Care and the Companionship Services Exemption Under the Fair Labor Standards Act (FLSA). 2013. http://www.dol.gov/whd/regs/compliance/whdfs25.htm (accessed 15 Jun 2015)

40 Warner M, Schenker N, Heinen MA, et al. The effects of recall on reporting injury and poisoning episodes in the National Health Interview Survey. Inj Prev 2005;11:282-7. 